\title{
TFRS 9 Kapsamında Faiz Oranı Swap Sözleşmelerinin Muhasebeleștirilmesi, Değerlemesi ve Raporlaması
} (Araştırma Makalesi)

\author{
Accounting, Evaluation and Reporting of Interest Rate Swap Contracts Under \\ TFRS 9
}

Doi: 10.29023/alanyaakademik.990033

\section{Ömer Burak PAKSOY}

Öğr.Gör.Dr., Alanya Alaaddin Keykubat Üniversitesi Gazipaşa MRB Meslek Yüksekokulu, Yönetim ve Organizasyon Bölümü,

omer.paksoy@alanya.edu.tr,

Orcid No:0000-0002-1273-5915.

Bu makaleye atıfta bulunmak için: Paksoy, Ö. B. (2022). "TFRS 9 Kapsamında Faiz Oranı Swap Sözleşmelerinin Muhasebeleștirilmesi, Değerlemesi ve Raporlaması”, Alanya Akademik Bakış, 6(1), Sayfa No. 1629-1651.

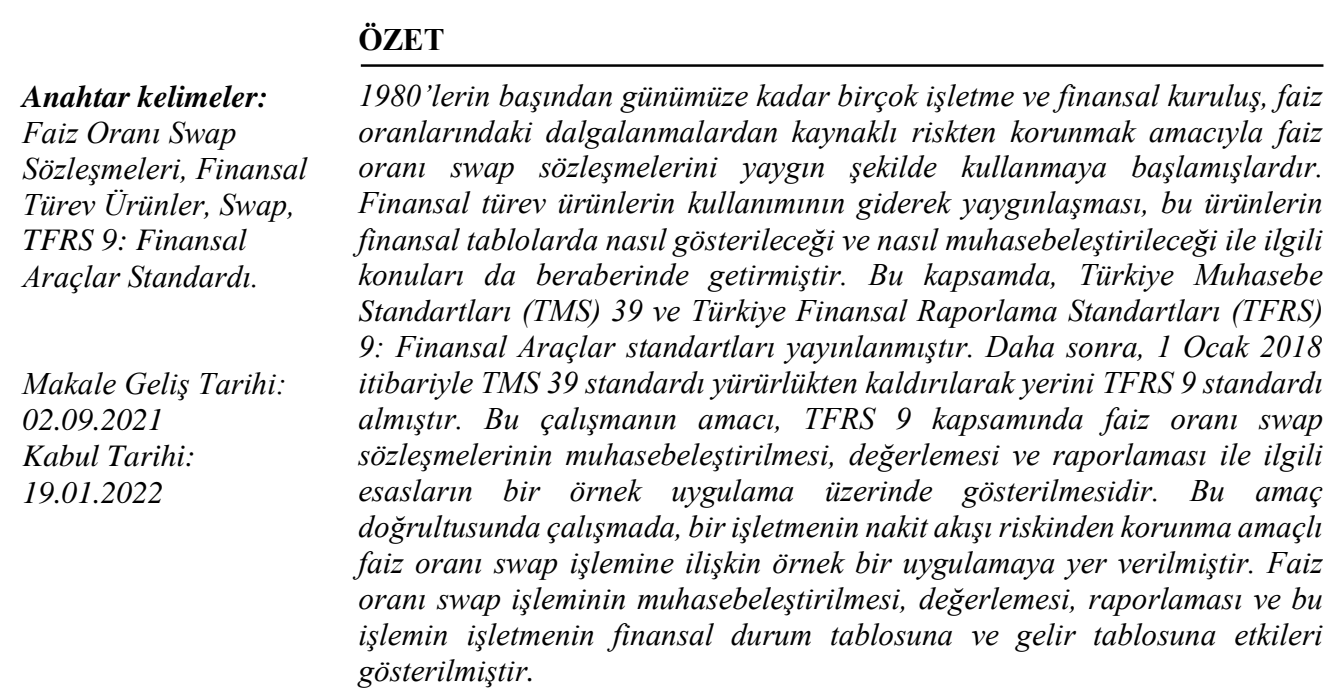

Keywords:

Interest Rate Swap

Contracts,

Financial

Derivative

Products, Swap,

TFRS 9 Standard.

\section{ABSTRACT}

Since the early 1980s, many businesses and financial institutions have started to use interest rate swap contracts in order to avoid the risk of interest rate fluctuations. The widespread use of financial derivatives has brought along issues related to how these products will be presented in the financial statements and how they will be accounted for. In this context, Turkish Accounting Standards (TMS) 39 and Turkish Financial Reporting Standards (TFRS) 9: Financial Instruments standards have been published. Later, as of January 1, 2018, TMS 39 standard was abolished and replaced by TFRS 9 standard. The purpose of this study is to demonstrate the principles of accounting, valuation and reporting of interest rate swap contracts under TFRS 9 on a sample application. For this purpose, a sample application 
regarding the interest rate swap transaction of an enterprise is included in the study. Accounting, valuation and reporting of the interest rate swap transaction and the effects of this transaction on the balance sheet and income statement of the company are shown.

\section{GİRIŞ}

1970'li yılların sonlarından günümüze kadar piyasa faiz oranlarının hem seviyelerinde hem de volatilitelerinde görülen önemli artışlar, ticari işletmelerin ve finansal kuruluşların önemli ölçüde yüksek faiz oranı riskleri ile karşılaşmalarına neden olmuştur. Faiz oranı riskine maruz kalmak, işletmeler için ciddi sonuçlara yol açabilmektedir. Örneğin, birçok finansal kuruluş ve işletme, kısa vadeli değişken faiz oranlı borçlarla uzun vadeli sabit faiz oranlı varlıklarını finanse etmektedir. Bu tür işletmeler, piyasadaki kısa vadeli faiz oranlarının beklenmedik bir şekilde yükseldiği zamanlarda zarara uğrayabilmektedirler. Çünkü varlıklarına verilen sabit getiri oranları için ödemek zorunda oldukları kısa vadeli faiz maliyetleri piyasa faiz oranları ile birlikte yükselmektedir. Diğer yandan, bu işletmeler kısa vadeli piyasa faiz oranlarındaki beklenmedik düşüşten ise kazanç sağlayabilmektedirler. Sermaye piyasalarında faize dayalı vadeli işlemler, faize dayalı opsiyonlar ve faiz oranı swap sözleşmeleri gibi yeni finansal ürünlerin piyasaya sürülmesi ve geliştirilmesi, işletmelerin faiz oranı riskine maruz kalmasını azaltmaya yönelik ihtiyaçlarına cevap verebilmektedir.

İşletmelerin son dönemlerde sıklıkla finansal türev ürünleri kullanmaya başladıklarından dolayı bu ürünlerin finansal tablolarda ve raporlamalarda gösterimi ve muhasebeleştirilmesi gibi konular önem kazanmıştır. Bu çalışmada, bir işletmenin faiz oranı swap işlemine ilişkin örnek bir uygulamaya yer verilmiştir. İşletmenin nakit akış riskinden korunmaya yönelik faiz oranı swap sözleşmesinin muhasebeleştirilmesi, değerlemesi ve raporlaması TFRS 9 kapsamında incelenmiştir. Çalışma ile, özellikle nakit akış riskinden korunmak amaçlı faiz oranı swap sözleşmelerinin muhasebeleştirilme yöntemi ve esasları hakkında standart hükümlerine göre örnek bir uygulama üzerinde inceleme yapılarak işletmelere bir yol haritası oluşturulması ve literatüre katkı sağlanması hedeflenmektedir. Bu amaç doğrultusunda, çalışma beş ana bölüme ayrılmıştır. İlk olarak faiz oranı swap sözleşmesi ile ilgili bu alanda yapılan çalışmalara ait literatür taramasına yer verilmiş olup daha sonra faiz oranı swap sözleşmeleri ve genel işleyişi hakkında genel bilgilere yer verilmiştir. Çalışmanın son bölümünde ise örnek bir faiz swap sözleşmesi uygulaması üzerinden TFRS 9 kapsamında muhasebeleştirilme, değerleme, raporlama işlemleri ve swap işlemi sonucunda işletmenin finansal durum tablosuna ve gelir tablosuna etkileri gösterilmiştir.

\section{LITERATÜR TARAMASI}

1 Ocak 2018 tarihi itibariyle TMS 39 standardının yerini alan TFRS 9 standardının uygulanması üç aşamada gerçekleştirilmektedir (Telci, 2021; Oracle, 2020; Deloitte, 2013): (i) Finansal Araçların Sınıflandırılması ve Ölçülmesi, (ii) Finansal Varlıklarda Değer Düşüklüğü, (iii) Riskten Korunma (Hedge Accounting).

TFRS 9 standardının yürürlüğe girmesiyle birlikte yurt içinde ve yurt dışında finansal araçlar ile ilgili birçok çalışma yapılmıştır. Literatürde, standart kapsamında işletmelerin raporlamaları, kurumsallaşma ilkeleri, finansal araçların vergisel boyutları gibi konular olduğu gibi riskten korunma muhasebesi, değerleme yöntemlerinin avantajları ve dezavantajları, 
alacak riskleri gibi konular da çok sayıda bulunmaktadır. Faiz oranı swap sözleşmeleri ile ilgili yurt içinde yapılan çalışmalara bakıldığında ise genellikle swap işlemlerinin riskten korunma aracı olarak kullanılması, muhasebeleştirilmesi, değerleme ve raporlama konuları ele alındığı görülmektedir. Bu alanda yapılan bazı çalışmalar ise aşağıda gösterilmektedir:

İpek (2020), TFRS kapsamında riskten korunma muhasebesini teorik olarak incelemiş ve Türkiye'de uygulanabilirliğine dair bir firmada vaka çalışması gerçekleştirmiştir. Çalışma sonucunda, analize tabi tutulan işletmenin riskten korunma muhasebesini uygulaması ve uygulamaması durumunda ne gibi sonuçlarla karşılaşabileceği gösterilmiştir.

Gökgöz (2019), çalışmasında TFRS 9 standardı kapsamında ticari alacaklara ilişkin kredi risklerinin belirlenmesini, beklenilen kredi zararlarının hesaplanmasını ve zararların muhasebeleştirilmesini incelemektedir. Çalışma sonucunda TFRS 9 standardının ticari alacaklara ilişkin zarar karşılıklarının ayrılmasında TMS 39 standardından farklılığı gösterilmektedir.

Koçak Şen ve Sözbilir (2019), çalışmalarında TFRS 9 standardının finansal türev ürünlerle ilgili ilkelerinden yola çıkarak bir swap işlemine ilişkin örnek uygulama üzerinden muhasebeleştirilmesi yöntemi hususunda bir yol haritası oluşturulmasını amaçlamaktadır. Çalışmada, uluslararası bir üretim işletmesinin nakit akış riskinden korunmak amacıyla gerçekleştirdiği faiz swap işleminin TFRS 9 kapsamında muhasebeleştirme süreci gösterilmektedir.

Dinç ve Atasel (2018), çalışmalarında BOBİ FRS kapsamında riskten korunma muhasebesi ile ilgili hükümleri inceleyerek örnek uygulamalar üzerinde muhasebeleştirme sürecini göstermişlerdir. Çalışma sonucunda BOBİ FRS kapsamında riskten korunma muhasebesi ile ilgili işletmelerin kullanabilecekleri bir hesap planı önerilmiş ve bu hesapların nasıl kullanılacağına dair örnekler ayrıntılı olarak açıklanmıştır.

Çakır ve Sabuncu (2016), TMS kapsamında riskten korunma amaçlı türev ürünlerin muhasebeleştirilmesini incelemişlerdir. Çalışmada, riskten korunma muhasebesinin uygulanması ile özkaynak hesap grubunda bazı yeni hesaplara ihtiyaç duyulduğu sonucuna ulaşılmıştır.

Tuncay ve Cengiz (2016), TFRS 9 kapsamında riskten korunma amaçlı bir swap örneği üzerinden muhasebeleştirme, değerleme ve raporlama sürecini incelemişlerdir. Çalışmada ilgili muhasebe kayıtları standart hükümleri doğrultusunda gerçekleştirilmiş ve bilanço-gelir tablosuna etkileri gösterilmiştir.

İşseveroğlu (2014), BİST 100 endeksindeki firmaların finansal araçlarını TMS 39'a göre değerlemelerini ve raporlamalarını incelemiştir. Çalışma sonucunda bazı firmaların gerçeğe uygun değer ile finansal varlıklarını değerlediğini ve değerleme farklarının da özkaynaklarda raporladığını göstermiştir.

Çına Bal ve Öztürk (2013), yabancı para birimi ile bir maddi duran varlık alımı ile ilgili nakit akış riskinden korunmak amacıyla hazırlanan bir forward sözleşmesinin TMS 39 kapsamında muhasebeleştirilmesini ve değerleme ilkelerini incelemişlerdir. Çalışma sonucunda, forward sözleşmesinin TMS 39 standardına uygun olarak yapılan muhasebe kayıtları ve finansal durum tablosuna etkisi gösterilmektedir. 
Ocakoğlu (2013), çalışmasında türev ürünlerin değerleme esasları ile finansal tablolara etkilerini ve muhasebeleştirilme sürecini incelemektedir. Çalışmada, KGK tarafından yayınlanan TMS 32, TMS 39, TFRS 7 ve TFRS 9 standartları kapsamında tüm türev ürünler ile ilgili muhasebe kayıtları örnek uygulamalar üzerinden gösterilmiştir.

Başçı (2003), vadeli işlem piyasası aracı olarak swapın işleyişi ve finansal piyasalardaki kullanımını incelemiştir. Çalışmada bir swap uygulaması gösterilerek sadece bankaların değil aynı zamanda kredi değeri düşük firmalar açısından da tercih edilmesi gereken bir araç olduğunu göstermeye çalışmıştır.

Literatür genel olarak incelendiğinde TFRS 9 standardı kapsamında birçok finansal türev araçlar ile ilgili çalışmaların olduğu görülmektedir. Ancak, faiz oranı swap sözleşmelerinin ele alındığı çalışmalar ise az sayıda yer almaktadır. Faiz swapları ile ilgili yapılan çalışmalarda, genellikle faiz swapları ile birlikte diğer finansal türev araçlarının da muhasebeleştirilmesi TFRS 9 kapsamında ele alınmıştır. Bu çalışma, yeni hesapların kullanımı, gerçeğe uygun değerlerinin hesaplanması ve kayıt sistemi açısından önceki yapılan çalışmalar ile benzerlikler göstermektedir. Ancak, nakit akış riskinden korunma amaçlı faiz oranı swap sözleşmeleri ile ilgili Türkiye'de uygulama eksikliğinin bulunması ve Türkiye'de faiz swap işlemlerinin çoğunlukla bankalar tarafından yapılması nedeniyle bu çalışma, işletmeler tarafından da kullanımının artırılması ve kullanım alanının genişletilmesi açısından önem arz etmektedir. $\mathrm{Bu}$ yüzden çalışmanın, faiz oranı swap sözleşmelerinin TFRS 9 kapsamında muhasebeleştirilmesi ve değerlemesi süreçlerinin örnek uygulama üzerinden incelenmesi açısından literatüre katkı sağlayacağı düşünülmektedir.

\section{FAİZ ORANI SWAP SÖZLEŞMELERİ}

Faiz oranı swap sözleşmesi, basit tanımıyla gelecekteki faiz ödemelerinin belirli bir anapara tutarına dayalı olarak başka bir faiz ödemesi ile takas edildiği bir forward sözleşmesidir (Korkmaz, 2020: 77; Kıyılar, 1998: 84). Faiz oranı swap sözleşmeleri, bir bono/tahvil veya krediden gelecek tüm faiz ödemelerini değiştirmek için iki taraf arasında yapılan sözleşmeler şeklinde de tanımlanabilmektedir. İşletmeler, bankalar veya yatırımcılar arasında gerçekleştirilebilir. Swaplar, finansal türev ürün sözleşmelerinden biridir. Swapın değeri, iki faiz ödemesi akışının temelindeki değerden türetilmektedir (Jermann ve Yue, 2017: 1-2). Swaplar, bu hareketlerin swap piyasasının etkinliğini doğrudan etkilemesi nedeniyle faiz oranı hareketlerine bağlıdır. Bu nedenle faiz oranlarının niteliği hakkında bilgi sahibi olmak gerekir. Faiz oranlarındaki dalgalanmaların açıklamaları ve nedenleri genellikle tartışmalara neden olmaktadır. Bunun nedenlerinden biri, faiz oranı değişikliklerini etkileyen faktörler hakkında yetersiz bilgi birikimidir. Diğer bir neden ise değişimleri etkileyen süreçlerin karmaşıklığıdır. $\mathrm{Bu}$ nedenle, tecrübeli uzmanların bile faiz oranlarındaki değişiklikleri tam olarak öngörmesi bir yana açıklamaları bile çok zor olabilmektedir (Prosic, 2015: 29). Swap çeşitleri arasındaki faiz oranı swap sözleşmelerini para swap sözleşmelerinden ayıran en temel farklılık, anaparanın takasa konu olmaması sadece faiz ödemelerinin karşılıklı şekilde değiştirilmesidir. Böylece risk sadece faiz ödemeleri ile sınırlı kalabilmektedir. Bu nedenle faiz oranı swap sözleşmeleri diğer türev ürünlere kıyasla daha fazla rağbet görmektedir (Başçı, 2003: 25).

Faiz oranı swap sözleşmelerinin temel olarak 5 çeşidi bulunmaktadır (Kızılkaya, 2016). Bunlar: (i) Sabit Faiz-Değişken Faiz Swap1, (ii) Değişken Faiz-Değişken Faiz Swap1, (iii) Vadeden Önce Son Verme Hakkı Veren Swaplar, (iv) Vadeli (forward) Swaplar, (v) Faiz Oranını Sonradan Belirleyen Swaplardır. 
Faiz oranı swap işlemlerine genelde neden olan işlemler arasında, değişken faizli fon sağlayabilme becerisine karşın sabit faizli fon sağlamada karşılaşılan problemler, bazı piyasalardaki vadelerin kısa olması, işletmelerin farklı piyasalarda farklı kredi değerliliğine sahip olması ve piyasalardaki yapısal ve kurumsal farklılıklar sayılabilmektedir (Yılmaz ve Şahin, 2009: 395).

Faiz oranı swap sözleşmeleri, faiz oranlarındaki değişikliklere karşı riskten korunma (hedge) veya spekülatif amaçlar için kullanılabilmektedir (Arzova ve Şahin, 2021; Çıtak ve Kurt, 2020; Türmob, 2020).

Olumsuz faiz oranı hareketlerinden korunmak veya sabit ve değişken oranlı borçlar arasında dengeyi sağlamak için faiz oranı swap sözleşmeleri kullanılabilir (Çıtak ve Kurt, 2020: 15). Faiz oranı swap sözleşmeleri, her iki tarafın da bir bankanın sunduğundan daha iyi borçlanma oranları elde ederek faiz ödemesi değişiminden yararlanmasını sağlar (Kurar ve Çetin, 2016: 409). Faiz oranı swap sözleşmeleri, banka gibi bir finansal aracı kurum tarafından da düzenlenebilir. Böylece karşı taraflar asla bir araya gelmez. Ancak, bir karşı tarafın temerrüde düşmesi durumunda, orijinal faiz ödemelerini karşılama yükümlülüğü asıl borçluda kalır. Ancak bu karşı taraf riski, takas bir finansal aracı kurum tarafından düzenlenirse azaltılabilir veya ortadan kaldırılabilir. Faiz oranı swap sözleşmeleri, işletmelerin diğer faiz oranı türevlerinden daha uzun bir süre korunmasına olanak tanır, ancak işletmelerin faiz oranlarındaki olumlu hareketlerden yararlanmasına izin vermez.

Varlık fiyatları, büyük ölçüde dalgalanabilir ve faiz oranı hareketinin yanı sıra siyasi ve ekonomik belirsizliklerden de güçlü bir şekilde etkilenebilir. Faiz oranı swap sözleşmelerini bu şekilde kâr amacı ile kullanan taraf spekülatif hareket edebilmektedir. Vadeli işlemler ile işlem yapan spekülatörler, kaldıraç etkisini kullanarak daha az sermaye ile daha fazla kazanç elde edebilmektedir. Ayrıca vadeli işlemler piyasasında spekülatörler sayesinde işlem hacimleri ve likidite artmaktadır (Leonard ve Srinivasan, 2016: 29).

\subsection{Faiz Oranı Swap Sözleşmelerinin Genel İşleyişi}

Genel olarak bir faiz oranı swap sözleşmesindeki iki taraf, sabit faiz oranlı ve değişken faiz oranlı alım satım yapmaktadır (Kawaller, 2007: 15). Faiz swap işlemi, bir tarafın değişken faiz oranı sunan menkul kıymetleriyle ilişkili riski korumaya alması, diğerinin ise daha muhafazakar bir varlık tutarken potansiyel kazançtan yararlanabilmesidir. Bu bir kazan-kazan stratejisidir, ancak aynı zamanda sıfır toplamlı bir oyundur. Bir tarafın takas yoluyla elde ettiği kazanç, diğer tarafın kaybına eşit olacaktır. Risk etkisiz hale getirilirken bir şekilde bir taraf biraz para kaybedecektir (Saunders, 1999: 58). 
Faiz oranı swap sözleşmesinin genel işleyişi aşağıda şekil ile şematize edilmiştir:



Şekil 1. Faiz Oranı Swap Sözleşmelerinin Genel İşleyişi ve Faiz Ödemeleri

Yukarıdaki şekilde de görüleceği üzere, $A B C$ ve XYZ işletmeleri piyasadan temin ettikleri farklı faiz oranlarını karşılıklı şekilde takas ederek fayda sağlamaya çalışmaktadır. Burda swap işlemi ile birlikte, $\mathrm{ABC}$ işletmesi sabit faizli ödemelerini değişken faiz ödemesine çevirirken XYZ işletmesi ise değişken faiz ödemelerini sabit faiz ödemesine çevirmektedir.

Swap işleminde tarafların farklı üstünlükleri ön plana çıkmaktadır. Örneğin kredi değerliliği yeterli olmayan bir işletme, piyasadan kredi temin edebilmek için piyasa faiz oranlarının rayicinin bir hayli üzerinde teklif alabilmektedir. Karşı tarafta ise piyasadan istediği şekilde uygun şartlarda kredi temin edebilen kredi değerliliği yüksek olan bir işletme bulunmaktadır.

Yukarıdaki şekilde verilen swap işleminin sonucunda taraflar ve aracı banka kazanç elde etmektedirler. Faiz oranı swap sözleşmelerinde nadiren de olsa bir aracı swap bankasının olmadığı durumlar da olabilmektedir. Bu durumda, şekildeki aracı swap bankası ortadan kalkmaktadir.

\subsection{Faiz Oranı Swap Sözleşmelerinin TFRS 9 Kapsamında Muhasebeleştirilmesi}

Faiz oranı swap sözleşmelerinin kullanım amaçları arasında riskten korunma ve spekülasyon yer almaktadır. Sözleşmeye taraf olan işletme veya finansal kuruluş, hangi amaçla bu swap işlemini yapıyorsa bu işlemler sonucunda oluşacak kâr veya zararın muhasebeleştirilmesi ve raporlanması da ona göre değişkenlik gösterecektir.

Gelecekteki nakit akışlarındaki dalgalanmalar; faiz oranlarındaki, döviz kurlarındaki, hisse senedi fiyatlarındaki veya emtia fiyatlarındaki değişikliklerden kaynaklanabilir. Bir nakit akışının riske karşı korunması, muhasebeleştirilen borçla ilgili riskin etkilerinden kaynaklanan değişikliklere maruz kalmaya karşı korunmasını ifade eder. Riskten korunma, bir varlığın gerçeğe uygun değerinin (GUD) veya nakit akışlarının değişkenliğini dengelemek amacıyla yapılabilmektedir. Riskten korunma aracı ile finansal riskten korunan kalemin gerçeğe uygun değerindeki değişikliklerin aynı finansal durum tablosu içinde ayarlanması, riskten korunma muhasebesi olarak adlandırılır. Daha doğrusu, riskten korunma muhasebesi, takas işlemine ilişkin kâr/zararı, korunan kalemle ilgili kâr/zarar ile düzeltir (Arzova ve Şahin, 2021; Koçak Şen ve Sözbilir, 2019; Tuncay ve Cengiz, 2016).

Gerçeğe uygun değer riskinden korunmak için riskten korunan kalemin bu değişikliklerin sonucunda oluşan kâr veya zararlar değerleme tarihinde gelir tablosunda raporlanır. Böylece, 1634 
swap işleminin bir tarafı kazancını, diğer taraf ise kaybını aynı dönemde raporladığından dengelenme sağlanmış olacaktır. Finansal riskten korunan kalemin defter değeri, korunan riske atfedilebilen gerçeğe uygun değer değişiklikleri için düzeltilir ve bu gerçeğe uygun değer değişiklikleri gelir tablosunda muhasebeleştirilir (Koçak Şen ve Sözbilir, 2019; Tuncay ve Cengiz, 2016).

Riskten korunma muhasebesinin yeterliliği için aşağıdaki koşulların sağlanması gerekmektedir (Babaoğlu ve Öztürk, 2020: 383; Prosic, 2015: 35):

- Önceden belirlenmiş ve belgelenmiş riskten korunma ilişkisi bulunmalıdır.

- Açıkça tanımlanmış bir hedge riski bulunmalıdır.

- Korunma aracının belirlenmiş riskten korunma konusunu dengelemede oldukça etkili olması beklenmektedir.

- Riskten korunma konusu kalemin korunulan finansal risk ile ilişkilendirilebilen gerçeğe uygun değeri ve nakit akışları ile riskten korunma aracının gerçeğe uygun değerinin güvenilir bir şekilde ölçülebilir olması gerekmektedir.

Finansal türev ürünler ile ilgili TMS 39 ve TFRS 9 standartlarında yer alan düzenlemeler bazı farklılıklar göstermektedir. Çalışmanın da konusunu oluşturan ilgili türev ürünün sınıflandırılması, ilk kez kayda alınması, değerlemesi ve raporlaması konularında ortaya çıkan standartlar arasındaki farklılıkların karşılaştırılmalı olarak gösterimi aşağıdaki tabloda özetlenmektedir.

Tablo 1. TMS 39 ve TFRS 9 Standartlarındaki Düzenlemelere İlişkin Karşılaştırma Tablosu

\begin{tabular}{|c|c|c|}
\hline \multicolumn{3}{|c|}{ SINIFLANDIRMA ESASLARI } \\
\hline & $T M S 39$ & TFRS 9 \\
\hline 1 & $\begin{array}{l}\text { Gerçeğe Uygun Değer Farkı Kâr/Zarara } \\
\text { Yansitılan Finansal Varlıklar }\end{array}$ & $\begin{array}{l}\text { Gerçeğe Uygun Değer Farkı Kâr/Zarara Yansıtılan } \\
\text { Finansal Varlıklar }\end{array}$ \\
\hline 2 & $\begin{array}{l}\text { Vadeye Kadar Elde Tutulacak Finansal } \\
\text { Varlıklar }\end{array}$ & $\begin{array}{l}\text { Gerçeğe Uygun Değer Farkı Diğer Kapsamlı Gelire } \\
\text { Yansıtılan Finansal Varlıklar }\end{array}$ \\
\hline 3 & Satışa Hazır Finansal Varlıklar & $\begin{array}{l}\text { İtfa Edilmiş Maliyeti Üzerinden Değerlenen } \\
\text { Finansal Varlıklar }\end{array}$ \\
\hline \multicolumn{3}{|c|}{ İLK KEZ MUHASEBELEŞTİRME ESASLARI } \\
\hline 1 & $\begin{array}{l}\text { Gerçeğe Uygun Değerle Değerlenerek } \\
\text { Muhasebeleştirilir. }\end{array}$ & $\begin{array}{l}\text { Gerçeğe Uygun Değerle Değerlenerek } \\
\text { Muhasebeleştirilir. }\end{array}$ \\
\hline \multicolumn{3}{|c|}{ SONRAKİ DÖNEMLERDE DEĞERLEME ESASLARI } \\
\hline 1 & $\begin{array}{l}\text { Gerçeğe Uygun Değer Farkı Kâr/Zarara } \\
\text { Yansitılan Finansal Varlıklar Gerçeğe } \\
\text { Uygun Değerle Değerlenir }\end{array}$ & $\begin{array}{l}\text { Gerçeğe Uygun Değer Farkı Kâr/Zarara Yansıtılan } \\
\text { Finansal Varlıklar Sonraki Dönemlerde de Gerçeğe } \\
\text { Uygun Değeri Üzerinden Değerlenir. }\end{array}$ \\
\hline 2 & $\begin{array}{l}\text { Vadeye Kadar Elde Tutulacak Finansal } \\
\text { Varlıklar İtfa Edilmiş Maliyet Değeriyle } \\
\text { Değerlenir }\end{array}$ & $\begin{array}{l}\text { Gerçeğe Uygun Değer Farkı Diğer Kapsamlı Gelire } \\
\text { Yansıtılan Finansal Varlıklar Sonraki Dönemlerde } \\
\text { de Gerçeğe Uygun Değeri Üzerinden Değerlenir }\end{array}$ \\
\hline 3 & $\begin{array}{l}\text { Satışa Hazır Finansal Varlıklar Gerçeğe } \\
\text { Uygun Değerle Değerlenir. }\end{array}$ & $\begin{array}{l}\text { İtfa Edilmiş Maliyeti Üzerinden Değerlenen } \\
\text { Finansal Varlıklar Sonraki Dönemlerde de İtfa } \\
\text { Edilmiş Maliyet Değeri Üzerinden Değerlenir. }\end{array}$ \\
\hline \multicolumn{3}{|c|}{ FAİZ VE KUR FARKLARININ DURUMU } \\
\hline 1 & $\begin{array}{l}\text { GUD Farkı K/Z'a Yansıtılan Finansal } \\
\text { varlıklarda Kur Farkından Doğan Kâr } \\
\text { Veya Zarar Faiz İle Ayrıştırılmadan } \\
\text { Kâr/Zarara Yansıtılmaktadır }\end{array}$ & $\begin{array}{l}\text { Gerçeğe Uygun Değer Farkı Kâr/Zarara Yansıtılan } \\
\text { Finansal Varlıklarda Alım Satım Amaçlı Elde } \\
\text { Tutulanlarda Kur Farkından Doğan Kâr veya Zarar }\end{array}$ \\
\hline
\end{tabular}




\begin{tabular}{|c|c|c|}
\hline & & $\begin{array}{l}\text { Faiz İle Ayrıştırmaya Tabi Tutulmadan Doğrudan } \\
\text { Kâr/Zarara Yansıtılmaktadır. }\end{array}$ \\
\hline 2 & $\begin{array}{l}\text { Vadeye Kadar Elde Tutulacak Finansal } \\
\text { Varlıklarda Kur Farkından Doğan Kâr } \\
\text { veya Zarar Faiz İle Ayrıştırılmadan } \\
\text { Kâr/Zarara Yansıtılmaktadır }\end{array}$ & $\begin{array}{l}\text { İtfa Edilmiş Maliyeti Üzerinden Değerlenen } \\
\text { Finansal Varlıklarda Faizlere İlişkin Olanlar } \\
\text { Kâr/Zarara; Piyasa Fiyatlarının Değişmesinden } \\
\text { Kaynaklanan Kısımlar ise Özkaynaklarda Finansal } \\
\text { Varlıklar Değerleme Farkı Olarak Kaydedilir. }\end{array}$ \\
\hline 3 & $\begin{array}{l}\text { Satışa Hazır Finansal Varlıklarda Faizlere } \\
\text { İlişkin Olanlar Kâr/Zarara; Piyasa } \\
\text { Fiyatlarının Değişmesinden Kaynaklanan } \\
\text { Kısımlar ise Özkaynaklarda Finansal } \\
\text { Varlıklar Değerleme Farkı Olarak } \\
\text { Kaydedilir. }\end{array}$ & \\
\hline \multicolumn{3}{|c|}{ DEĞERLEME FARKLARININ DURUMU } \\
\hline 1 & $\begin{array}{l}\text { Gerçeğe Uygun Değer Farkı Kâr/Zarara } \\
\text { Yansitılan Finansal Varlıkların } \\
\text { Değerlemesi Sonucu Ortaya Çıkan } \\
\text { Farklar Gelir Tablosunda Kâr/Zarara } \\
\text { Yansıtılmaktadır. } \\
\end{array}$ & $\begin{array}{l}\text { Gerçeğe Uygun Değer Farkı Kâr/Zarara Yansıtılan } \\
\text { Finansal Varlıkların Değerlemesi Sonucu Ortaya } \\
\text { Çıkan Farklar Gelir Tablosunda Kâr/Zarara } \\
\text { Yansıtılmaktadır }\end{array}$ \\
\hline 2 & $\begin{array}{l}\text { Vadeye Kadar Elde Tutulacak Finansal } \\
\text { Varlıkların Değerlemesi Sonucu Ortaya } \\
\text { Çıkan Farklar Gelir Tablosunda } \\
\text { Kâr/Zarara Yansıtılmaktadır }\end{array}$ & $\begin{array}{l}\text { Gerçeğe Uygun Değer Farkı Diğer Kapsamlı Gelire } \\
\text { Yansıtılan Finansal Varlıkların Değerlemesi } \\
\text { Sonucu Ortaya Çıkan Farklar Özkaynaklarda } \\
\text { Finansal Varlıklar Değerleme Farkları Hesabında } \\
\text { İzlenmektedir }\end{array}$ \\
\hline 3 & $\begin{array}{l}\text { Satışa Hazır Finansal Varlıkların } \\
\text { Değerlemesi Sonucu Ortaya Çıkan } \\
\text { Farklar Özkaynaklarda Finansal Varlıklar } \\
\text { Değerleme Farkları Hesabında } \\
\text { Gösterilmektedir. }\end{array}$ & $\begin{array}{l}\text { İtfa Edilmiş Maliyet Değeri İle Değerlenen } \\
\text { Finansal Varlıkların Değerlemesi Sonucu Ortaya } \\
\text { Çıkan Farklar Gelir Tablosunda Kâr/Zarara } \\
\text { Yansıtılmaktadır. }\end{array}$ \\
\hline
\end{tabular}

Kaynak: Özulucan vd. 2017, 246-247.

Yukarıdaki tabloda da görüleceği üzere, TMS 39 ve TFRS 9 kapsamında finansal varlıklar edinme ve elde tutulma nedenlerine göre sınıflandırılmaktadır. Her iki standartta da ilk kez muhasebeleştirme esasları aynı olup finansal varlıklar gerçeğe uygun değerleri ile değerlenerek muhasebeleştirilmektedir (Kaldırım ve Selvi, 2021: 29-30). Sonraki dönemlerde değerleme esaslarında ise gerçeğe uygun değerle değerlenen ve alım satım amacıyla elde tutulan finansal varlıklar ile satışa hazır finansal varlıklar, gerçeğe uygun değerle değerlenirken; vadeye kadar elde tutulacak finansal varlıklar ve itfa edilmiş maliyet değeriyle ölçülen finansal varlıklar itfa edilmiş maliyet değeriyle değerlenmektedir. TMS 39' da gerçeğe uygun değer farkı kâr/zarara yansitılan finansal varlıklar ve vadeye kadar elde tutulacak finansal varlıkların değerlemesinden ortaya çıkan değerleme farkları gelir tablosuna kâr/zarar şeklinde kaydedilirken, satışa hazır finansal varlıklara ilişkin ortaya çıkan farklar ise finansal durum tablosu ile ilişkilendirilerek özkaynaklarda finansal varlıklar değerleme farkları olarak kaydedilmektedir. TFRS 9'da ise alım satım amacıyla elde tutulan ve gerçeğe uygun değerle değerlenen finansal varlıklar ile itfa edilmiş maliyetle değerlenen finansal varlıklara ilişkin ortaya çıkan değerleme farkları gelir tablosuna kâr/zarar şeklinde kaydedilirken, gerçeğe uygun değer farkı diğer kapsamlı gelire yansıtılan finansal varlıklara ilişkin ortaya çıkan değerleme farkları finansal durum tablosu ile ilişkilendirilerek özkaynaklarda finansal varlıklar değerleme farkları olarak kaydedilmektedir (Özulucan vd., 2017: 247; Telci, 2021). 


\section{METODOLOJI}

\subsection{Araştırmanın Amacı ve Kapsamı}

Çalışma ile, özellikle nakit akış riskinden korunmak amaçlı faiz oranı swap sözleşmelerinin muhasebeleştirilme yöntemi ve esasları hakkında TFRS 9 hükümlerine göre örnek bir uygulama üzerinde inceleme yapılarak işletmelere bir yol haritası oluşturulması ve literatüre katkı sağlanması amaçlanmaktadır. Bu amaç doğrultusunda bir işletmenin faiz oranı swap işlemine ilişkin örnek bir uygulamaya yer verilmiştir.

\subsection{Yöntem}

$\mathrm{Bu}$ çalışmada nitel araştırma yöntemlerinden birisi olan örnek olay yöntemi kullanılmıştır. Sosyal bilimler alanında sıkça kullanılan örnek olay yönteminde, bir olayı veya işlemi oluşturan tüm detayları ranımlamak ve incelemek, ilgili olayın belirli bir durumuna yoğunlaşarak genele ulaşabilmek amaçlanmaktadır. Bu yöntem, bütünsel betimleme ve açıklamaya odaklanarak bilimsel sorulara yanıt aramada kullanılan ayırt edici bir yaklaşım olarak görülmektedir (Deveci ve Deveci, 2018: 127-128).

Örnek olay çalışmasında ayrıntılı olarak ele alınan özel bir örnek ile genele ulaşılmaktadır. Araştırma konusunun merkezini oluşturan örnek olay gerçek ya da senaryoya dayalı hayali bir varlık ya da olay olabilir. Bu çalışmada, finansal türev ürünlerden olan faiz oranı swap sözleşmelerinin nakit akışı riskinden korunma amacıyla TFRS 9 kapsamında muhasebeleştirilmesine yönelik bir örnek uygulama gösterilmektedir.

\section{UYGULAMA}

BRS Sanayi ve Ticaret AŞ. 31 Aralık 2014 tarihinde 100 milyon TL nominal değerli, 5 yıl vadeli, yıllık kupon ödemeli, TRLibor+\%3 faiz oranlı bir tahvil ihraç etmiştir. İşletme, nakit akışını riskten korumak amacıyla ve değişken faiz oranlarındaki artış riskinden kaçınabilmek için tahvil faiz kupon ödemelerindeki oranı \%18'e sabitlemek istemektedir. Tahvil ihracı ile aynı tarihte yine aynı tutarda bir faiz oranı swap sözleşmesi imzalamıştır. Swap sözleşmesine istinaden, BRS işletmesi, X Bankasından 100 milyon TL nominal tutar üzerinden TRLibor (yıllık) faiz tahsil edecek ve karşılığında X Bankasına \%15 sabit faiz ödemesi yapacaktır. Aşağıdaki şekil-2'de swap sözleşmesine taraf olanlar ve ödenecek faiz oranları şematize edilmektedir.

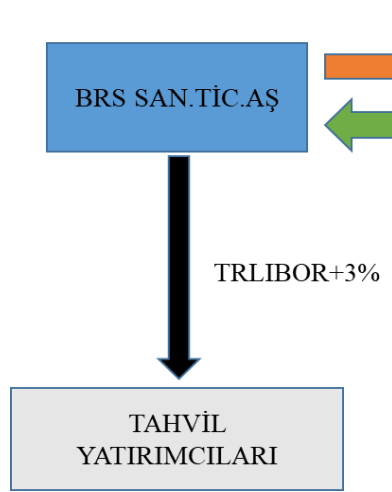

$\% 15$ SABİT FAİZ ÖDEMESİ

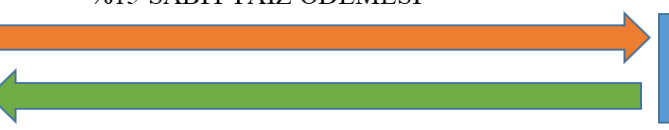

TRLIBOR DEĞİŞKEN FAİZ ÖDEMESİ

Şekil 2. Örnek Faiz Oranı Swap Sözleşmesinin İşleyişi ve Faiz Ödemeleri 


\subsection{Swap Sözleşmesi ile Kurulan Riskten Korunma İlişkisinin Dökümantasyonu}

TFRS 9'un dökümantasyon gerekliliklerinin niteliği, TMS 39'daki hükümlerden çok farklı değildir. Riskten korunma ilişkisinin başlangıcında resmî tanımlama ve dökümantasyon mevcut olmalıdır. Sonuç olarak, dökümantasyon bakış açısından, riskten korunma muhasebesini başlatmak için idari çalışmalar yoğun şekilde yapılmalıdır (Koçak Şen ve Sözbilir, 2019; Tuncay ve Cengiz, 2016).

Riskten korunma ilişkisinin dökümantasyonu, riskten korunma işlemini açıklayan bir belgedir. "Riskten korunma dökümantasyonu" terimi TFRS'de tam olarak tanımlanmamış olsa da, TFRS 9 paragraf 6.4.1'de belgelere nelerin yazılması gerektiği belirtilmiştir. Bunlar:

- Risk yönetiminin konusu,

- Risk yönetimi hedefi ve stratejisi,

- Riskten korunma arac1,

- Hedge edilen kalem,

- Korunulan risk,

- Riskten korunma türü,

- Hedge etkinliği değerlendirmesidir.

Aşağıdaki tablo 2'de örnek uygulamada belirtilen riskten korunma ilişkisinin dökümantasyonu gösterilmektedir.

Tablo 2. Swap Sözleşmesi ile Kurulan Riskten Korunma İlişkisinin Dökümantasyonu

\begin{tabular}{|c|c|}
\hline $\begin{array}{l}\text { Risk Yönetiminin } \\
\text { Konusu ve Stratejisi }\end{array}$ & $\begin{array}{l}\text { - Bu korunmanın amacı şirketin TL cinsinden ödediği tahvil kuponlarına } \\
\text { ilişkin ödemelerin nakit akışlarının değişkenliğini ortadan } \\
\text { kaldırmaktır. } \\
\text { - BRS İşletmesinin ihraç etmiş olduğu tahvillerin TRLibor'a ilişkin } \\
\text { nakit çıkışını \%15'e sabitlemek. } \\
\text { - Değişken faiz oranı riskinden korunmak amacıyla değişken faizi sabit } \\
\text { oranlı faize çevirmek amaçlanmaktadır. Piyasadan sabit faizli oran } \\
\text { bulmakta zorlanan işletme, faiz oranı swap sözleşmesi imzalayarak net } \\
\text { borcunu sabit faizli hale getirebilmektedir. }\end{array}$ \\
\hline Riskten Korunma Türü & - Nakit Akış Riskine Karşı Koruma \\
\hline Korunulan Risk & - Faiz Oran1 Riski \\
\hline Riskten Korunma Aracı & - Faiz Oranı Swap Sözleşmesi \\
\hline Riskten Korunan Kalem & - 5 Y1llık değişken faizli tahvilin nakit çıkış1 \\
\hline $\begin{array}{l}\text { Hedge Etkinliğinin } \\
\text { Değerlendirilmesi }\end{array}$ & $\begin{array}{l}\text { - Muhtemel riskten korunma etkinliği testi, riskten korunma kaleminin } \\
\text { gerçeğe uygun değerindeki veya nakit akışlarındaki değişikliklerin, } \\
\text { riskten korunan kalemin gerçeğe uygun değerindeki veya nakit } \\
\text { akışlarındaki değişiklikleri dengelemede oldukça etkili olup } \\
\text { olmayacağının ileriye dönük bir değerlendirmesidir. } \\
\text { - Kritik Koşullar Metodu: Bu niteliksel yöntem, her iki unsurun da } \\
\text { belirli kriterleri karşılaması koşuluyla, korunma aracı ile korunan } \\
\text { kalemin temel koşullarının karşılaştırılmasını içerir. Testler, bir } \\
\text { unsurun nakit akışlarındaki değişikliklerin diğerindeki zıt } \\
\text { değişikliklerle dengelenip dengelenmediğini gösterecektir. } \\
\text { - Tarafların kredi riski düşükse, riskten korunmanın etkinliğinin yüksek } \\
\text { olduğu kabul edilir. Riskten korunma aracı için karşı tarafin kredi riski } \\
\text { sürekli izlenir. }\end{array}$ \\
\hline
\end{tabular}




\subsection{Faiz Oranı Swap Sözleşmesinin Gerçeğe Uygun Değerlerinin Hesaplanması}

Bir faiz oranı swap sözleşmesinin gerçeğe uygun değeri, her iki taraftaki (yani alıcı ve ödeme tarafları) gelecekteki nakit akışlarının belirlenmesi ve bu nakit akışlarının uygun bir iskonto faktörü eğrisi kullanılarak iskonto edilmesi yoluyla hesaplanır. Swap sözleşmesinin netleşme tutarı, gerçeğe uygun değeri ve gerçeğe uygun değerindeki değişim aşağıdaki tablo.3'te gösterilmektedir.

Tablo 3. Swap Sözleşmesinin Gerçeğe Uygun Değeri ve Kümülatif Değişim

\begin{tabular}{|c|c|c|c|c|c|c|c|c|}
\hline $\begin{array}{c}\text { Bilanço } \\
\text { Tarihi }\end{array}$ & $\begin{array}{l}\text { TRLibor } \\
\text { (yıllık) \% }\end{array}$ & $\begin{array}{c}\text { Tahvil Faiz } \\
\text { Oranı } \\
(\text { TRLibor+3\%) }\end{array}$ & $\begin{array}{c}\text { Swap } \\
\text { Faiz } \\
\text { Oranı } \\
\%\end{array}$ & $\begin{array}{l}\text { Tahvil } \\
\text { Kupon } \\
\text { Ödemesi } \\
\text { (TL) }\end{array}$ & $\begin{array}{c}\text { Swap } \\
\text { Bankasından } \\
\text { Elde Edilen } \\
\text { Tahsilat } \\
\text { (TL) }\end{array}$ & \begin{tabular}{|c|} 
Swap \\
Sözleşmesinin \\
Netleşme \\
Tutarı \\
(TL)
\end{tabular} & \begin{tabular}{|c|} 
Swap \\
Sözleşmesinin \\
Gerçeğe Uygun \\
Değeri
\end{tabular} & \begin{tabular}{|c|} 
Swap \\
Sözleşmesinin \\
Gerçeğe Uygun \\
Değerindeki \\
Değișim
\end{tabular} \\
\hline \multicolumn{9}{|l|}{31.12 .2014} \\
\hline 31.12 .2015 & 10,02 & 13,02 & 15,00 & 13.020 .000 & 10.020 .000 & 4.980 .000 & 15.120 .000 & 15.120 .000 \\
\hline 31.12 .2016 & 11,74 & 14,74 & 15,00 & 14.740 .000 & 11.740 .000 & 3.260 .000 & 4.140 .000 & -10.980 .000 \\
\hline 31.12 .2017 & 11,18 & 14,18 & 15,00 & 14.180 .000 & 11.180 .000 & 3.820 .000 & 2.520 .000 & -1.620 .000 \\
\hline 31.12 .2018 & 15,28 & 18,28 & 15,00 & 18.280 .000 & 15.280 .000 & -280.000 & -1.080 .000 & -3.600 .000 \\
\hline 31.12 .2019 & 24,58 & 27,58 & 15,00 & 27.580 .000 & 24.580 .000 & -9.580 .000 & 0 & 1.080 .000 \\
\hline
\end{tabular}

Yukarıdaki tablodan da görüleceği üzere 31.12.2014 tarihinde ihraç edilen tahvilin ilk kupon ödemesi 31.12.2015 tarihinde yapılacaktır. Buna göre, 31.12.2014 tarihinde TRLibor yıllık faizi \% 10,02 şeklinde oluşmuştur. Tahvil faiz ödemesi aşağıdaki şekilde hesaplanmaktadır.

Tahvil Faizi $=$ Nominal Tutar $*$ TRLibor $(y 1 l l k)+\% 3]=100.000 .000 *(\% 10,02+\% 3)=$ 13.020.000 TL

BRS İşletmesinin Swap Bankasına yapacağı ödeme \%15 sabit faiz oranı üzerinden hesaplanmış olup her y1l 15.000.000 TL (100.000.000 TL x \%15) şeklinde gerçekleşmektedir. Buna karşılık, Swap Bankası ise BRS İşletmesine ilgili yıl için oluşan TRLibor yıllık faiz üzerinden ödeme yapacaktır. Buna göre, BRS İşletmesinin Swap Bankasından elde edeceği tahsilat 10.020.000 TL (100.000.000 TL x \%10,02) olacaktır. Böylece, swap sözleşmesinin netleşme tutarı aşağıdaki gibi hesaplanmaktadır.

Swap sözleşmesi netleşme tutarı $=15.000 .000 \mathrm{TL}-10.020 .000 \mathrm{TL}=4.980 .000 \mathrm{TL}$

31.12.2015 tarihinde TRLibor yıllık faizi \%11,74 şeklinde oluşmuştur. Tahvil faiz ödemesi aşağıdaki şekilde hesaplanmaktadır.

Tahvil Faizi $=$ Nominal Tutar $*$ TRLibor $(\mathrm{y} 1 \mathrm{ll} \mathrm{k})+\% 3]=100.000 .000 *(\% 11,74+\% 3)=$ 14.740.000 TL

BRS İşletmesinin Swap Bankasına ödeyeceği ödeme \%15 sabit faiz oranı üzerinden hesaplanan 15.000.000 TL'dir. Buna karşılık, Swap Bankası ise BRS İşletmesine ilgili yıl için oluşan TRLibor yıllık faiz üzerinden ödeme yapacaktır. Buna göre, BRS İşletmesinin Swap Bankasından elde edeceği tahsilat 11.740.000 TL $(100.000 .000$ TL x \%11,74) olacaktır. Böylece, swap sözleşmesinin netleşme tutarı aşağıdaki gibi hesaplanmaktadır.

Swap sözleşmesi netleşme tutarı $=15.000 .000 \mathrm{TL}-11.740 .000 \mathrm{TL}=3.260 .000 \mathrm{TL}$

31.12.2016 tarihinde TRLibor yıllık faizi \%11,18 şeklinde oluşmuştur. Tahvil faiz ödemesi aşağıdaki şekilde hesaplanmaktadır. 
Tahvil Faizi $=$ Nominal Tutar $*$ TRLibor $(\mathrm{y} 1 \mathrm{ll} \mathrm{k})+\% 3]=100.000 .000 *(\% 11,18+\% 3)=$ 14.180.000 TL

BRS İşletmesinin Swap Bankasına ödeyeceği ödeme \%15 sabit faiz oranı üzerinden hesaplanan 15.000.000 TL'dir. Buna karşılık, Swap Bankası ise BRS İşletmesine ilgili yıl için oluşan TRLibor yıllık faiz üzerinden ödeme yapacaktır. Buna göre, BRS İşletmesinin Swap Bankasından elde edeceği tahsilat 11.180.000 TL $(100.000 .000$ TL x \%11,18) olacaktır. Böylece, swap sözleşmesinin netleşme tutarı aşağıdaki gibi hesaplanmaktadır.

Swap sözleşmesi netleşme tutarı $=15.000 .000 \mathrm{TL}-11.180 .000 \mathrm{TL}=3.820 .000 \mathrm{TL}$

31.12.2017 tarihinde TRLibor yıllık faizi \%15,28 şeklinde oluşmuştur. Tahvil faiz ödemesi aşağıdaki şekilde hesaplanmaktadır.

Tahvil Faizi $=$ Nominal Tutar $*$ TRLibor $(\mathrm{y} 1 \mathrm{ll} \mathrm{k})+\% 3]=100.000 .000 *(\% 15,28+\% 3)=$ 18.280.000 TL

BRS İşletmesinin Swap Bankasına ödeyeceği ödeme \%15 sabit faiz oranı üzerinden hesaplanan 15.000.000 TL'dir. Buna karşılık, Swap Bankası ise BRS İşletmesine ilgili yıl için oluşan TRLibor yıllık faiz üzerinden ödeme yapacaktır. Buna göre, BRS İşletmesinin Swap Bankasından elde edeceği tahsilat 15.280.000 TL $(100.000 .000$ TL x \%15,28) olacaktır. Böylece, swap sözleşmesinin netleşme tutarı aşağıdaki gibi hesaplanmaktadır.

Swap sözleşmesi netleşme tutarı $=15.000 .000 \mathrm{TL}-15.280 .000 \mathrm{TL}=-280.000 \mathrm{TL}$

31.12.2018 tarihinde TRLibor yıllık faizi \%24,58 şeklinde oluşmuştur. Tahvil faiz ödemesi aşağıdaki şekilde hesaplanmaktadır.

Tahvil Faizi $=$ Nominal Tutar $*$ TRLibor $(\mathrm{y} 1 \mathrm{ll} \mathrm{k})+\% 3]=100.000 .000 *(\% 24,58+\% 3)=$ 27.580.000 TL

BRS İşletmesinin Swap Bankasına ödeyeceği ödeme \%15 sabit faiz oranı üzerinden hesaplanan 15.000.000 TL'dir. Buna karşılık, Swap Bankası ise BRS İşletmesine ilgili yıl için oluşan TRLibor yıllık faiz üzerinden ödeme yapacaktır. Buna göre, BRS İşletmesinin Swap Bankasından elde edeceği tahsilat 24.580.000 TL (100.000.000 TL x \%24,58) olacaktır. Böylece, swap sözleşmesinin netleşme tutarı aşağıdaki gibi hesaplanmaktadır.

Swap sözleşmesi netleşme tutarı $=15.000 .000 \mathrm{TL}-24.580 .000 \mathrm{TL}=-9.580 .000 \mathrm{TL}$

\section{3. Örnek Uygulamaya İlişkin Muhasebe Kayıtları}

TFRS 9: Finansal Araçlar Standartı kapsamında türev ürünlerde meydana gelen değişimlerin korunmada etkin olan kısmı özkaynaklarda, etkin olmayan kısmı ise gelir tablosu hesaplarında gösterilmelidir. BRS İşletmesi, geçmişe yönelik etkinlik testlerini rasyo analizi metodunu kullanarak yapmaktadır. Bu yöntem ile örnek işletmenin nakit akış riskinden koruma amaçlı düzenlenen swap işleminin davranışları analiz edilerek korunma aracı ile riskten korunan kalemi aynı olduğundan swap sözleşmesinin gerçeğe uygun değeri ile tahvilin gerçeğe uygun değerlerinin yıllık değişimleri aynıdır.

Örnek uygulamaya ilişkin muhasebe kayıtları, Kamu Gözetimi Kurumu'nun yayınladığı 2018 tarihli "Finansal Raporlama Standartlarına Uygun Hesap Planı Taslağı"na göre gerçekleştirilmiştir. 


\section{$\underline{2014}$ yılı kayıtları:}

Buna göre, BRS İşletmesinin 31.12.2014 tarihinde ihraç etmiş olduğu 100.000.000 TL'lik tahvilin muhasebe kaydı aşağıdaki gibidir.

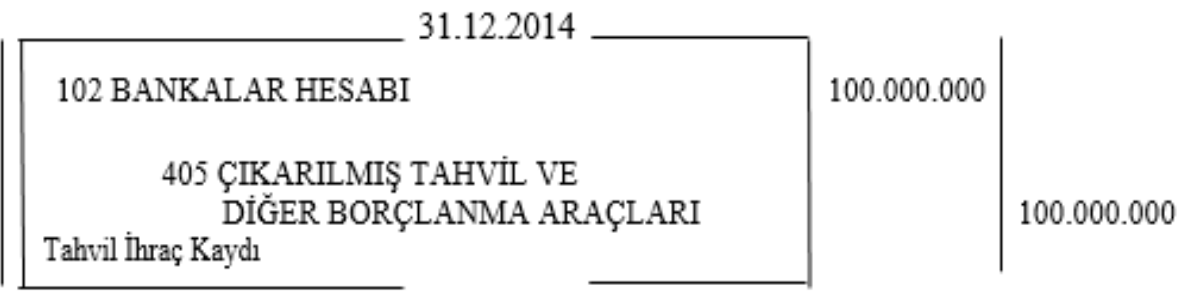

Yukarıdaki yevmiye kaydında, BRS İşletmesinin finansman ihtiyacı nedeniyle ihraç etmiş olduğu 100.000.000 TL'lik tahvilin ihraç kaydı yapılmıştır. Buna göre, 102 Bankalar hesabına borç kaydedilir ve karşılığında 405 çıkarılmış tahvil ve diğer borçlanma araçları hesabına alacak kaydedilir.

31.12 .2014


Faiz swap sözleşmesi nominal tutar üzerinden yapıldığından ve vade sonunda bir borç-alacak ilişkisi doğurmadığından dolayı swap sözleşmesinin tutarı yukarıda gösterilen yevmiye kaydında nazım hesaplara kaydedilmiştir. Ayrıca, başlangıçta swap sözleşmesinin gerçeğe uygun değeri sıfır olduğu için 2014 yılı için yevmiye kaydı yapılmamıştır.

\section{$\underline{2015}$ yılı kayıtları:}

BRS İşletmesinin 31.12.2015 tarihinde yapacağı yevmiye kayıtları aşağıdaki gibidir.

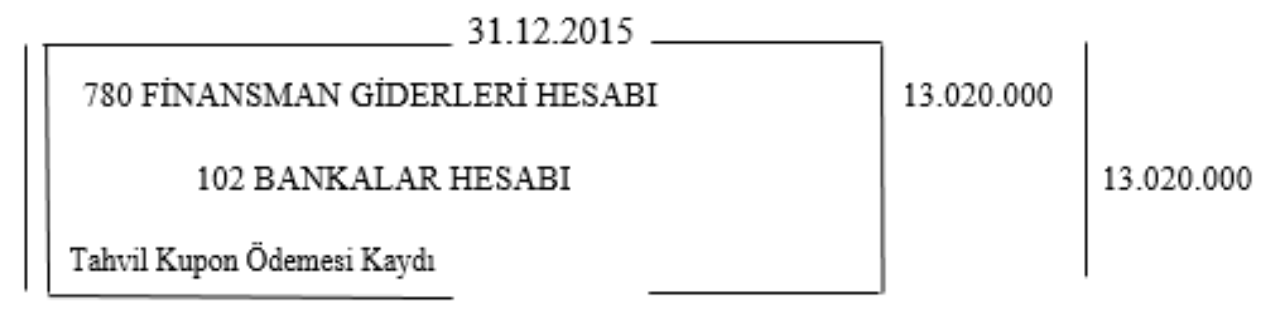

Yukarıdaki yevmiye kaydı, tahvil kupon ödemesinin kaydını göstermektedir. 31.12.2015 tarihinde 13.020.000 TL faiz ödemesi yapılacaktır. Bu nedenle, 780 Finansman Giderleri hesabına borç ve 102 Bankalar hesabına ise alacak kaydedilir. 
31.12 .2015

119 TÜREV FINANSAL VARLIKLAR HS.

561 NAKITT AKIŞ RISKINDEN KORUNMA KAZANÇLARI (KAYIPLARI) HESABI

15.120 .000

Swap Sözleşmesinin Gerçeğe Uygun Değer Değişimi

Yukarıdaki yevmiye kaydında ise swap sözleşmesinin gerçeğe uygun değerindeki değişim kaydı gösterilmektedir. Swapın gerçeğe uygun değerindeki değişim 15.120.000 TL şeklinde gerçekleşmiş ve bu değişim tutarı, nakit akış riskinden korunma nedeniyle gerçekleştiği ve artış yönlü olduğu için özkaynaklarda 561 Nakit Akış Riskinden Korunma Kazançları (Kayıpları) hesabına alacak kaydedilmiştir. Swap sözleşmesinin gerçeğe uygun değeri ise finansal durum tablosunda varlıklar sınıfinda yer almaktadır. Bu yüzden, 119 Türev Finansal Varlıklar hesabına borç kaydedilmiştir.

31.12.2015

780 FINANSMAN GIDERLERI HESABI 4.980 .000

102 BANKALAR HESABI

Swap Netlę̧me Tutarı Kaydı

Yukarıdaki yevmiye maddesinde ise swap sözleşmesinin tarafları arasındaki ödenecek ve tahsil edilecek faiz tutarları netleştirilir. Bu kayıtta, BRS İşletmesi Swap Bankasına nette 4.980.000 TL ödeme yapmıştır. Bu yüzden, 780 Finansman Giderleri hesabına borç, 102 Bankalar hesabına ise alacak kaydedilir.

\section{6 yılı kayıtları:}

BRS İşletmesinin 31.12.2016 tarihinde yapacağı yevmiye kayıtları aşağıdaki gibidir.

31.12.2016

780 FINANSMAN GIDERLERI HESABI 14.740 .000

14.740 .000

Tahvil Kupon Ödemesi Kaydı

Yukarıdaki yevmiye maddesi, tahvil kupon ödemesinin kaydını göstermektedir. 31.12.2016 tarihinde 14.740.000 TL faiz ödemesi yapılacaktır. Bu nedenle, 780 Finansman Giderleri hesabına borç ve 102 Bankalar hesabına ise alacak kaydedilir. 
31.12.2016

561 NAKİT AKIŞ RISKİNDEN KORUNMA

KAZANÇLARI (KAYIPLARI) HESABI

10.980 .000

309 TÜREV ARAÇLARDAN BORÇLAR HS.

10.980 .000

Swap Sözleşmesinin Gerçeğe Uygun Değer Değişimi

Yukarıdaki yevmiye maddesinde ise swap sözleşmesinin gerçeğe uygun değerindeki değişim kaydı gösterilmektedir. Swapın gerçeğe uygun değerindeki değişim 10.980.000 TL şeklinde gerçekleşmiş ve bu değişim tutarı, nakit akış riskinden korunma nedeniyle gerçekleştiği ve azalış yönlü olduğu için özkaynaklarda 561 Nakit Akış Riskinden Korunma Kayıpları hesabına borç kaydedilmiştir. Swap sözleşmesinin gerçeğe uygun değeri ise 309 Türev Araçlardan Borçlar hesabına alacak kaydedilir.

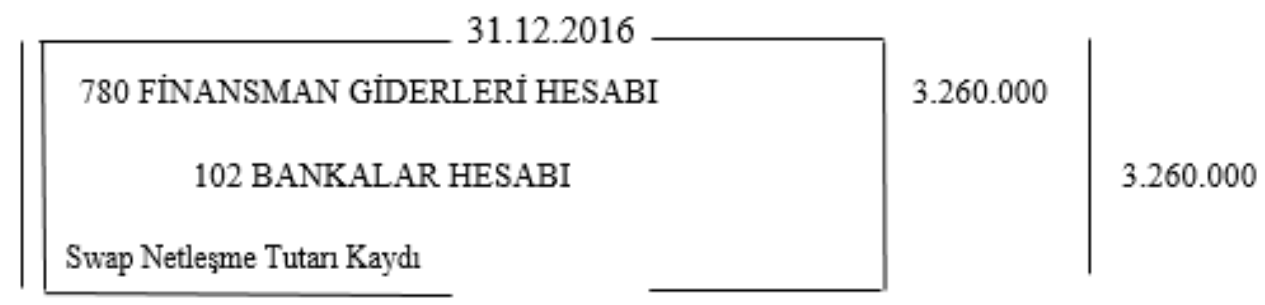

Yukarıdaki yevmiye maddesinde ise swap sözleşmesinin tarafları arasındaki ödenecek ve tahsil edilecek faiz tutarları netleştirilir. Bu kayıtta, BRS İşletmesi Swap Bankasına nette 3.260.000 TL ödeme yapmıştır. Bu yüzden, 780 Finansman Giderleri hesabına borç, 102 Bankalar hesabına ise alacak kaydedilir.

\section{$\underline{2017 \text { yilı kayıtları: }}$}

BRS İşletmesinin 31.12.2017 tarihinde yapacağı yevmiye kayıtları aşağıdaki gibidir.

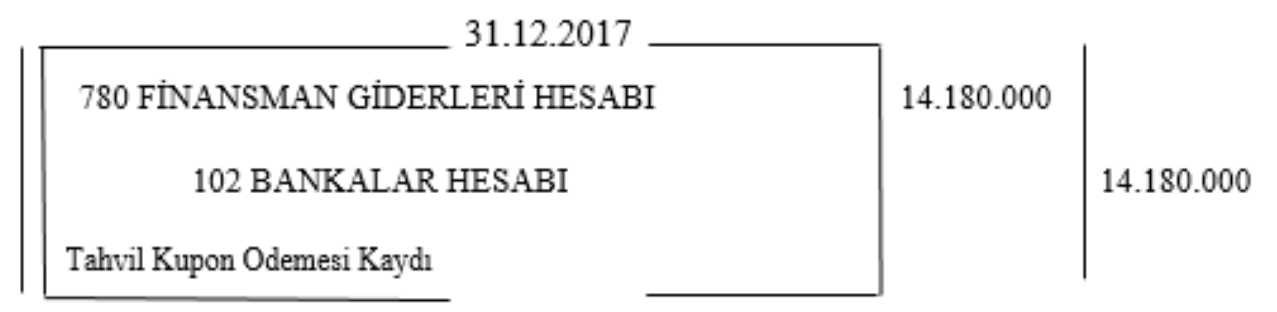

Yukarıdaki yevmiye maddesi, tahvil kupon ödemesinin kaydını göstermektedir. 31.12.2017 tarihinde 14.180.000 TL faiz ödemesi yapılacaktır. Bu nedenle, 780 Finansman Giderleri hesabına borç ve 102 Bankalar hesabına ise alacak kaydedilir. 
31.12.2017

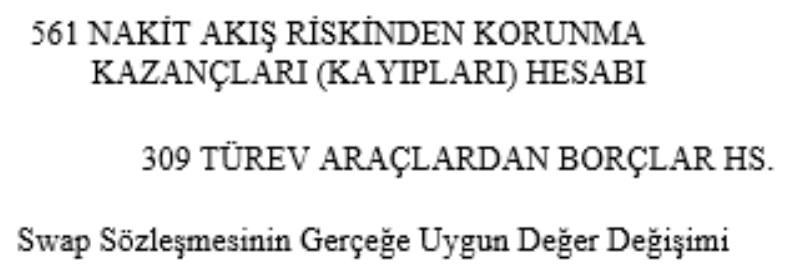

Yukarıdaki yevmiye maddesinde ise swap sözleşmesinin gerçeğe uygun değerindeki değişim kaydı gösterilmektedir. Swapın gerçeğe uygun değerindeki değişim 1.620.000 TL şeklinde gerçekleşmiş ve bu değişim tutarı, nakit akış riskinden korunma nedeniyle gerçekleştiği ve azalış yönlü olduğu için özkaynaklarda 561 Nakit Akış Riskinden Korunma Kayıpları hesabına borç kaydedilmiştir. Swap sözleşmesinin gerçeğe uygun değeri ise 309 Türev Araçlardan Borçlar hesabına alacak kaydedilir.

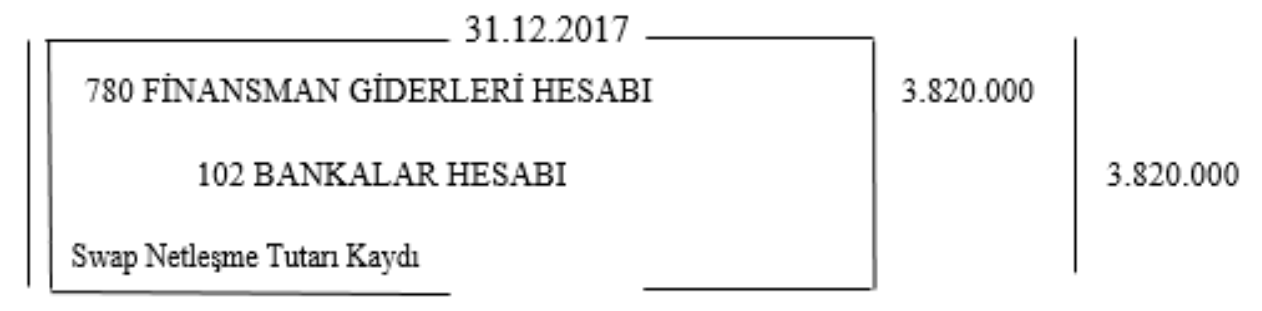

Yukarıdaki yevmiye maddesinde ise swap sözleşmesinin tarafları arasındaki ödenecek ve tahsil edilecek faiz tutarları netleştirilir. Bu kayıtta, BRS İşletmesi Swap Bankasına nette 3.820.000 TL ödeme yapmıştır. Bu yüzden, 780 Finansman Giderleri hesabına borç, 102 Bankalar hesabına ise alacak kaydedilir.

\section{8 vilı kavitları:}

BRS İşletmesinin 31.12.2018 tarihinde yapacağı yevmiye kayıtları aşağıdaki gibidir.

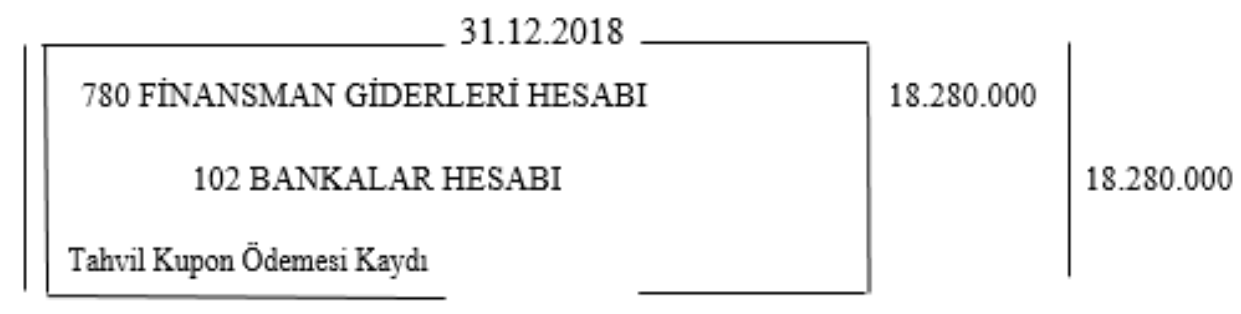

Yukarıdaki yevmiye maddesi, tahvil kupon ödemesinin kaydını göstermektedir. 31.12.2018 tarihinde 18.280.000 TL faiz ödemesi yapılacaktır. Bu nedenle, 780 Finansman Giderleri hesabına borç ve 102 Bankalar hesabına ise alacak kaydedilir. 
31.12.2018

561 NAKITT AKIŞ RISSKINDEN KORUNMA

KAZANÇLARI (KAYIPLARI) HESABI

3.600 .000

309 TÜREV ARAÇLARDAN BORÇLAR HS.

3.600 .000

Swap Sözleş̧mesinin Gerçeğe Uygun Değer Değişimi

Yukarıdaki yevmiye maddesinde ise swap sözleşmesinin gerçeğe uygun değerindeki değişim kaydı gösterilmektedir. Swapın gerçeğe uygun değerindeki değişim 3.600.000 TL şeklinde gerçekleşmiş ve bu değişim tutarı, nakit akış riskinden korunma nedeniyle gerçekleştiği ve azalış yönlü olduğu için özkaynaklarda 561 Nakit Akış Riskinden Korunma Kayıpları hesabına borç kaydedilmiştir. Swap sözleşmesinin gerçeğe uygun değeri ise 309 Türev Araçlardan Borçlar hesabına alacak kaydedilir.

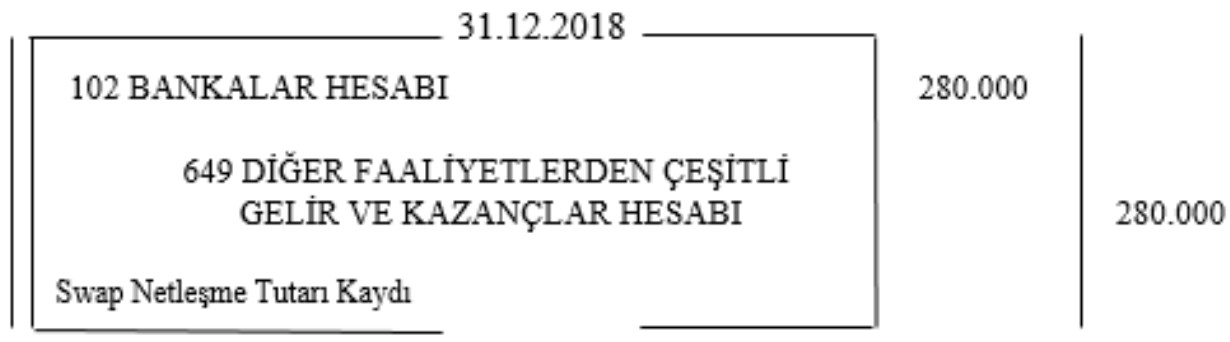

Yukarıdaki yevmiye maddesinde ise swap sözleşmesinin tarafları arasındaki ödenecek ve tahsil edilecek faiz tutarları netleştirilir. Bu kayıtta, BRS İşletmesi Swap Bankasından nette 280.000 TL tahsilat yapmıştır. Bu yüzden, 102 Bankalar Hesabına borç, 649 hesaba ise alacak kaydedilmiştir.

\section{9 yılı kayıtları:}

BRS İşletmesinin 31.12.2019 tarihinde yapacağı yevmiye kayıtları aşağıdaki gibidir.

31.12 .2019

405 ÇIKARILMIŞ TAHVIL VE

DIĞGR BORÇLANMA ARAÇLARI HESABI

100.000 .000

102 BANKALAR HESABI

Tahvil İtfa Kaydı

100.000 .000 
Yukarıdaki kayıtta tahvilin vadesi dolduğu için anapara tutarı ödenerek itfa kaydı gerçekleştirilmiştir.

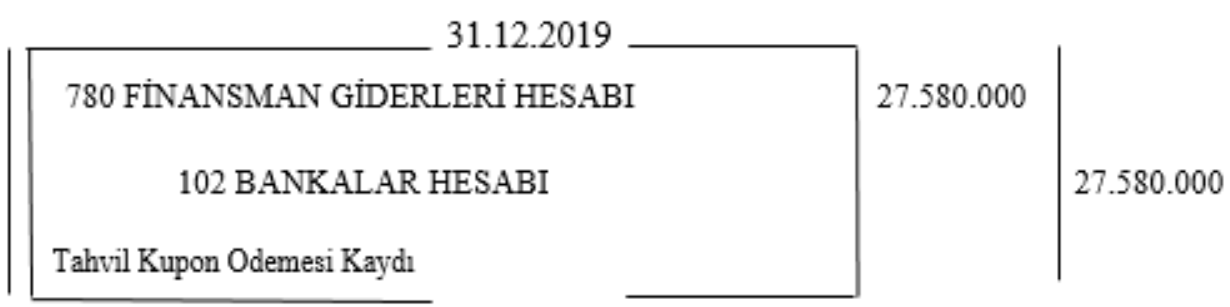

Yukarıdaki yevmiye maddesinde ise tahvil kupon ödemesinin kaydı gösterilmektedir. 31.12.2019 tarihinde 27.580.000 TL faiz ödemesi yapılacaktır. Bu nedenle, 780 Finansman Giderleri hesabına borç ve 102 Bankalar hesabına ise alacak kaydedilir.

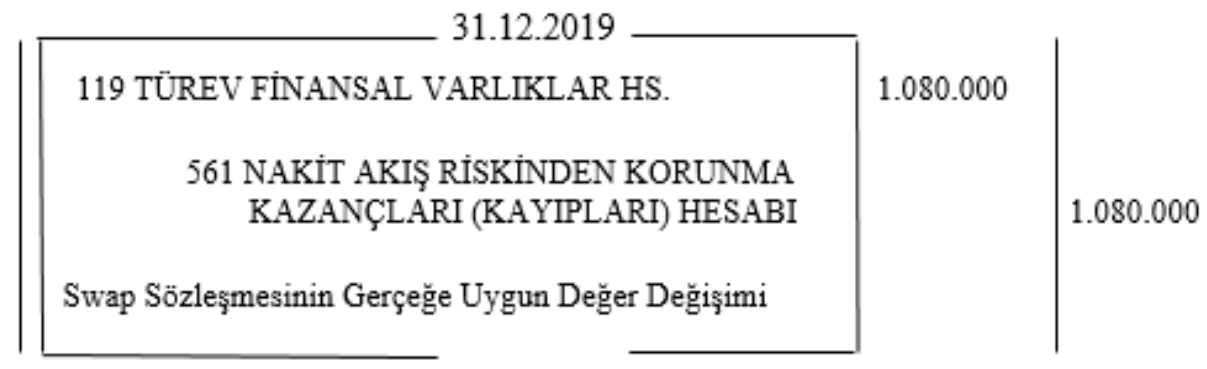

Yukarıdaki yevmiye maddesinde ise swap sözleşmesinin gerçeğe uygun değerindeki değişim kaydı gösterilmektedir. Swapın gerçeğe uygun değerindeki değişim 1.080.000 TL şeklinde gerçekleşmiş ve bu değişim tutarı, nakit akış riskinden korunma nedeniyle gerçekleştiği ve artış yönlü olduğu için özkaynaklarda 561 Nakit Akış Riskinden Korunma Kazançları hesabına alacak kaydedilmiştir. Swap sözleşmesinin gerçeğe uygun değeri ise 119 Türev Finansal Varlıklar hesabına borç kaydedilir.

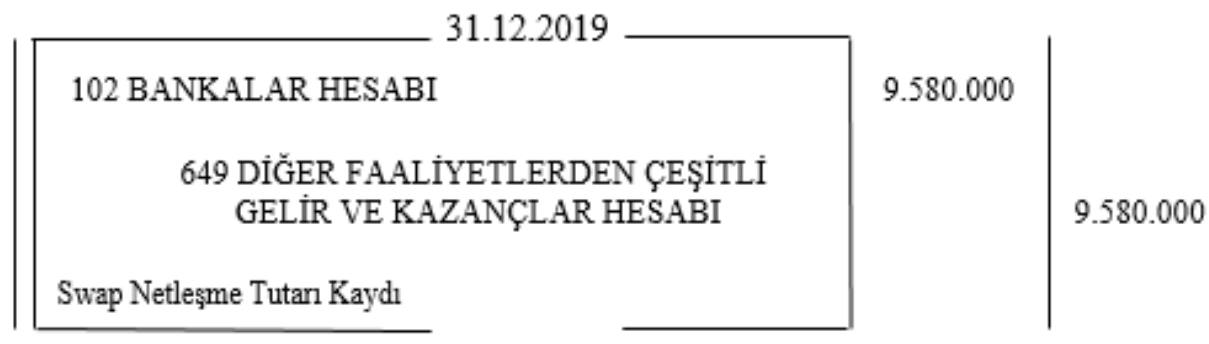

Yukarıdaki yevmiye maddesinde ise swap sözleşmesinin tarafları arasındaki ödenecek ve tahsil edilecek faiz tutarları netleştirilir. Bu kayıtta, BRS İşletmesi Swap Bankasından nette 9.580.000 TL tahsilat yapmıştır. Bu yüzden, 102 Bankalar hesabına borç, 649 hesaba ise alacak kaydedilmiştir. 
Çalışmada bir işletmenin nakit akış riskinden korunmak amacıyla gerçekleştirdiği faiz swap sözleşmesinin TFRS 9 standardı kapsamında muhasebeleştirilme süreci gösterilmiştir. Örnek uygulamada vade boyunca riskten korunmanın işletmenin gelir tablosunda yarattığı etki aşağıdaki tabloda gösterilmektedir.

Tablo 4. Riskten Korunmanın Gelir Tablosuna Etkisi

\begin{tabular}{|l|r|r|r|r|r|}
\hline $\begin{array}{l}\text { Gelir Tablosu } \\
\text { Kalemleri }\end{array}$ & $\begin{array}{l}\mathbf{0 1 . 0 1 . 2 0 1 5}- \\
\mathbf{3 1 . 1 2 . 2 0 1 5}\end{array}$ & $\begin{array}{l}\mathbf{0 1 . 0 1 . 2 0 1 6} \\
\mathbf{3 1 . 1 2 . 2 0 1 6}\end{array}$ & $\begin{array}{l}\mathbf{0 1 . 0 1 . 2 0 1 7 -} \\
\mathbf{3 1 . 1 2 . 2 0 1 7}\end{array}$ & $\begin{array}{l}\mathbf{0 1 . 0 1 . 2 0 1 8}- \\
\mathbf{3 1 . 1 2 . 2 0 1 8}\end{array}$ & $\begin{array}{l}\mathbf{0 1 . 0 1 . 2 0 1 9} \\
\mathbf{3 1 . 1 2 . 2 0 1 9}\end{array}$ \\
\hline $\begin{array}{l}\text { Faiz Gideri } \\
\text { (Tahakkuk eden faiz } \\
\text { kuponu) }\end{array}$ & 13.020 .000 & 14.740 .000 & 14.180 .000 & 18.280 .000 & 27.580 .000 \\
\hline $\begin{array}{l}\text { Faiz Gideri / Geliri } \\
\text { (Swap Netleşme } \\
\text { Tutarı) }\end{array}$ & 4.980 .000 & 3.260 .000 & 3.820 .000 & -280.000 & -9.580 .000 \\
\hline TOPLAM & 18.000 .000 & 18.000 .000 & 18.000 .000 & 18.000 .000 & 18.000 .000 \\
\hline
\end{tabular}

Yukarıdaki tablodan da görüleceği üzere işletme, nakit akış riskinden korunmak amacıyla tahvilin vadesine kadar her dönem sonunda nakit çıkışını 18.000.000 TL şeklinde sabitlemiştir. Faiz oranı swap sözleşmesi sayesinde tahakkuk eden tahvil faiz kuponu ödemeleri ile swap sözleşmesinden kaynaklı netleşme tutar ödemelerinin toplamı her dönem için sabitlenerek nakit akış riskinden korunma sağlanmıştır. Böylece, işletmenin ihraç etmiş olduğu tahvilin vade boyunca faiz ödemeleri sabit bir faiz oranı ile sabitlenerek değişken faiz riskinden korunma sağlanmaktadır.

Vade boyunca riskten korunmanın işletmenin finansal durum tablosunda yarattığı etki ise aşağıdaki tabloda özetlenmektedir:

Tablo 5. Riskten Korunmanın Finansal Durum Tablosuna Etkisi

\begin{tabular}{|l|r|r|r|r|r|}
\hline Bilanço Kalemleri & $\mathbf{3 1 . 1 2 . 2 0 1 5}$ & $\mathbf{3 1 . 1 2 . 2 0 1 6}$ & $\mathbf{3 1 . 1 2 . 2 0 1 7}$ & $\mathbf{3 1 . 1 2 . 2 0 1 8}$ & $\mathbf{3 1 . 1 2 . 2 0 1 9}$ \\
\hline Aktif & & & & & \\
\hline Kasa Hs. & 82.000 .000 & 64.000 .000 & 46.000 .000 & 28.000 .000 & -90.000 .000 \\
\hline Türev Fin. Varlıklar & 15.120 .000 & 15.120 .000 & 15.120 .000 & 15.120 .000 & 16.200 .000 \\
\hline Aktif Toplamı & 97.120 .000 & 79.120 .000 & 61.120 .000 & 43.120 .000 & -73.800 .000 \\
\hline Pasif & & & & & \\
\hline Finansal Borçlar & 100.000 .000 & 100.000 .000 & 100.000 .000 & 100.000 .000 & 0 \\
\hline Türev Fin. Yük. & 0 & 10.980 .000 & 12.600 .000 & 16.200 .000 & 16.200 .000 \\
\hline $\begin{array}{l}\text { Ert. Türev Ürün } \\
\text { Kazancı/Kaybı }\end{array}$ & 15.120 .000 & 4.140 .000 & 2.520 .000 & -1.080 .000 & 0 \\
\hline Kar/Zarar & -18.000 .000 & -36.000 .000 & -54.000 .000 & -72.000 .000 & -90.000 .000 \\
\hline Pasif Toplamı & 97.120 .000 & 79.120 .000 & 61.120 .000 & 43.120 .000 & -73.800 .000 \\
\hline
\end{tabular}

Yukarıdaki tabloda ise riskten korunma sonucunda işletmenin finansal durum tablosunda yarattığı etki gösterilmiştir. Buna göre, sözleşme tutarı swap sözleşmesinin yapıldığı tarihten itibaren finansal durum tablosunda izlenir ve sözleşme sonunda yükümlülüklerin son bulmasıyla finansal durum tablosundan çıkarılır. Swap sözleşmesinin gerçeğe uygun değerindeki değişimler finansal durum tablosunda özkaynaklarda "Nakit Akış Riskinden Korunma Kazançları (Kayıpları)" hesabında takip edilir. Sözleşme süresi sonunda ise riskten korunan araçtan doğan kâr veya zarar, faiz oranı swap sözleşmesi ile denkleştirileceğinden dolayı ilgili hesap kapatılır. 


\section{SONUÇ}

1980'lerde tanıtılan bir sermaye piyasası aracı olan faiz oranı swap sözleşmeleri, etkili bir faiz oranı koruma ve borç yönetimi aracı haline gelmiştir. Faiz oranı swap sözleşmeleri, iki veya üç yılı aşan vadelerde faiz oranı riskine karşı korunmada futures ve opsiyon işlemlerinden daha etkili olabilmektedir. Faiz oranı swap sözleşmeleri, finansal türevlerin genel özelliklerine uygun olarak uygulandığında daha etkin bir faiz oranı riski yönetimi, finansman maliyetlerinin düşürülmesi ve yatırılan fonların gelirlerinin artmasını sağlamaktadırlar.

Türkiye'de finansal türev ürünlerin muhasebeleştirilmesi, genel olarak Tek Düzen Muhasebe Sistemi ve Vergi Mevzuat hükümleri esas alınarak gerçekleştirilmektedir. Ancak, finansal raporlamalarda standartlaşma, gerçeğe uygun bilgi sunumu, finansal tabloların güvenirliliği ve karşılaştırılabilirliğinin sağlanması için TMS ve TFRS'ler ile yeni düzenlemeler getirilmiştir. Finansal araçlar ile ilgili 2009 yılında TMS 39 standardı yayınlanmış olup standardın karmaşık bir yapıya sahip olmasından dolayı yerine TFRS 9 standardı hazırlanmış ve 2018 yılında yürürlüğe girmiştir.

Tek Düzen Hesap Planı'nda finansal türev ürünler ile ilgili hesapların bulunmaması ve tekdüzeliğin sağlanamaması gibi nedenler ile muhasebeleştirme süreçlerinde yaşanan karmaşıklıkların giderilmesi amacıyla Kamu Gözetimi Muhasebe ve Denetim Standartları Kurumu tarafindan 2018 yılında yeni bir "Finansal Raporlama Standartlarına Uygun Hesap Planı Taslağı" oluşturulmuştur. Bu yeni hesap planı taslağında türev ürünler ile ilgili yeni hesaplar bulunmaktadır. Ancak Türkiye'deki finansal tablo kullanıcıları, yeni hesapların kullanımı ile ilgili örnek teşkil eden uygulamaların azlığı nedeniyle zorluk yaşamaktadır. Bu çalışma ile bir faiz oranı swap sözleşmesinin TFRS 9 kapsamında muhasebeleştirilmesi bir örnek üzerinde incelenmiş ve standart esasları açıklanmaya çalışılmıştır. Böylece çalışmanın, faiz oranı swap sözleşmesi kullanmak isteyen işletmeler için bir yol gösterici niteliğinde olabileceği düşünülmektedir.

Çalışmada bir işletmenin ihraç etmiş olduğu tahvilin değişken faiz ödemelerinin sabit faiz ile takasını gösteren örnek bir uygulamaya yer verilmiştir. Aracı swap bankası ile yapılan faiz oranı swap sözleşmesi imzalayan işletme, vade sonuna kadar nakit akış çıkışlarını sabitleyebilmiştir. Böylece tahvilin değişken faizlerinde meydana gelen değişimlere karşı nakit akışını riskten korumayı başarabilmiştir.

Çalışmada gösterilen uygulamada ulaşılan sonuçlar literatürde yer alan önceki çalışmalar ile bazı benzerlikler göstermektedir. Önceki çalışmalarda, farklı finansal türev araçlarının muhasebeleştirilmesi, değerlemesi ve raporlaması TFRS 9 kapsamında örnekleri üzerinden gösterilmiştir. Yeni hesapların kullanımı, gerçeğe uygun değerlerinin hesaplanması ve kayıt sistemi açısından benzerlikler mevcuttur. Ancak, nakit akış riskinden korunma amaçlı faiz oranı swap sözleşmeleri ile ilgili literatürde az sayıda çalışma bulunması ve Türkiye'de faiz swap işlemlerinin çoğunlukla bankalar tarafından yapılması nedeniyle bu çalışma, işletmeler tarafından da kullanımının artırılması ve kullanım alanının genişletilmesi açısından önem arz etmektedir. Ayrıca, faiz oranı swap sözleşmelerinin birçok türü bulunmakta olup çalışmada karşılıklı iki tarafın işlemleri esas alınmıştır. Buna karşılık sonraki çalışmalarda swap işlemine konu tarafların artırılması ve kur riski de uygulamaya konu edilebilir. $\mathrm{Bu}$ tür örnek uygulamaların, çeşitliliğin artırılmasına ve standartların anlaşılmasına katkı sunacağı düşünülmektedir. 


\section{KAYNAKÇA}

AMADEO, K. (2020). https://www.thebalance.com/interest-rate-swaps-3306248, (Erişim Tarihi: 15 Ocak 2021).

ARZOVA, S.B. \& ŞAHIN, B.Ş. (2021). “IBOR Reformu ve Riskten Korunma Muhasebesi”. Journal of Research in Business, 6(2): 454-469.

BABAOĞLU, G. ve ÖZTÜRK, E. (2020). "Riskten Korunma Muhasebesi Kapsamında Etkinlik Şartının Rasyo Analizi Yöntemi ile Tespiti”. Muhasebe ve Vergi Uygulamaları Dergisi, 13(2): 377-400.

BAŞÇI, E.S. (2003). "Vadeli İşlem Piyasası Aracı Olarak Swap'ın İşleyişi ve Finansal Piyasalardaki Kullanımları”. Gazi Üniversitesi Endüstriyel Sanatlar Eğitim Fakültesi Dergisi, 11(12): 18-33.

ÇAKIR, H.M. \& SABUNCU, B. (2016). "Riskten Korunma Amaçlı Türev Araçların Türkiye Muhasebe Standartları Kapsamında Muhasebeleştirilmesi”. Pamukkale Üniversitesi Sosyal Bilimler Enstitüsü Dergisi, 25: 121-137.

ÇINA BAL, E. \& ÖZTÜRK, V. (2013). “Türkiye Muhasebe Standardı TMS-39 Finansal Araçlar: Muhasebeleştirme ve Ölçüm Kapsamında Türev Ürünlerin Nakit Akış Riskinden Korunma Amaçlı Kullanımı: Forward Örneği”. İşletme Araştırmaları Dergisi, 5(2): 123-140.

ÇITAK, N. \& KURT, F. (2020). “İhracat Firmalarında Riskten Korunma Aracı Olarak Türev Ürünlerin Kullanımı”. Muhasebe Enstitüsü Dergisi, 62: 11-22.

DELOITTE (2013). "IFRS 9: Financial Instruments- high level summary". https://www2.deloitte.com/content/dam/Deloitte/ru/Documents/audit/ifrs-9-financialinstruments-en.pdf , (Erişim Tarihi: 15 Ocak 2021).

DEVECİ, B. \& DEVECİ, B. (2018). “Örnek Olay Çalışmasına İlişkin Teorik Bir Değerlendirme”. Social Sciences Studies Journal (SSSJournal), 4(13): 126-135.

DİNÇ, E. \& ATASEL, O.Y. (2018). "Büyük ve Orta Boy İşletmeler için Finansal Raporlama Standardı (BOBİ FRS) Kapsamında Riskten Korunma Muhasebesi ve Korunma Yedeği”. Süleyman Demirel Üniversitesi İktisadi ve İdari Bilimler Fakültesi Dergisi, 23(4): 1185-1204.

GÖKGÖZ, A. (2019). "TFRS 9 Finansal Araçlar Standardı Çerçevesinde Ticari Alacaklara İlişkin Beklenen Kredi Zararlarının Tespiti ve Muhasebeleştirilmesi”. Journal of Accounting, Finance and Auditing Studies, 5(2): 163-178.

HECKINGER, R. (2013). “Understanding Derivatives: Markets and Infrastructure, Chapter 1: Derivatives Overview". https://www.chicagofed.org/ /media/publications/understandingderivatives/understanding-derivatives-chapter-1-derivatives-overview-pdf.pdf?la=en, (Erişim Tarihi: 15 Ocak 2021).

HULL, J. (2012). “Options, Futures and Other Derivatives”. 8th Edition. Pearson Education Limited, USA. 
İPEK, A. (2020). "Riskten Korunma Muhasebesi ve Türkiye’de Uygulanabilirliği Üzerine Bir Vaka Çalışması”. Muhasebe ve Finansman Dergisi, 88 (Ekim): 75-96.

İŞSEVEROĞLU, G. (2014). "TMS 39 Kapsamında Finansal Varlıkların Sınıflandırılması ve Değerlemesi: Borsa İstanbul 100 Endeksindeki Şirketlerin Uygulamaları”. Uluslararası Yönetim İktisat ve İşletme Dergisi, 10(21): 87-106.

JERMANN, U.J. \& YUE, V.Z. (2017). “Interest Rate Swaps and Corporate Default”. Journal of Economic Dynamics and Control, 1-34.

KABLAN, A. (2005). “Türkiye'de Swap Sözleşmelerinin Muhasebeleştirilmesi ve Uygulamaları”, Yüksek Lisans Tezi, İstanbul Üniversitesi Sosyal Bilimler Enstitüsü İşletme Anabilim Dalı, İstanbul.

KALDIRIM, Z. \& SELVİ, Y. (2021). "Hibrid Sözleşmelerdeki Saklı Türevler”. Muhasebe Bilim Dünyası Dergisi, 23(Özel Say1): 24-41.

KAMU GÖZETIMİ KURUMU (2017). “TFRS 9 Finansal Araçlar”, https://kgk.gov.tr/Portalv2Uploads/files/DynamicContentFiles/T\%C3\%BCrkiye\%20M uhasebe\%20Standartlar\%C4\%B1/TMSTFRS2018Seti/TFRS/TFRS_9_2017\%20S\%C 3\%BCr\%C3\%BCm\%C3\%BC_2018.pdf, (Erişim Tarihi: 15 Ocak 2021).

KAWALLER, I.G. (2007). "Interest Rate Swaps: Accounting vs. Economics". Financial Analysis Journal, 63(2): 15-18.

KIYILAR, M. (1998). “Swap, Swap Türleri ve Swap İşlemlerinin Muhasebeleştirilmesi”. İÜ İşletme Fakültesi Dergisi, 27(1): 83-104.

KIZILKAYA, D. (2016). "Swap İşlemleri ve Faiz SWAP'ının (IRS) Temel Unsurları". https://silo.tips/download/sabit-faiz-oran-deiken-faiz-oran-swap-ilemleri-ve-faiz-swapnn-irs-temel-unsurla, (Erişim Tarihi: 15 Ocak 2021).

KOÇAK ŞEN, İ. \& SÖZBİLİR, H. (2019). "IFRS 9 Finansal Araçlar Standardı Kapsamında Finansal Türev Ürünlerin Muhasebeleştirilmesi: Swap Örneği”. Muhasebe Bilim Dünyası Dergisi, 21(4): 1008-1036.

KORKMAZ A. (2020). “Swap Sözleşmelerden Elde Edilen Gelirin Vergilendirilmesi”. Vergi Raporu, 244: 74-91.

KURAR, İ. \& ÇETIN, A.C. (2016). “Türev Araçlarının Risk Yönetim Fonksiyonu: Vadeli İşlem Piyasası Risk Yönetimi Üzerine Bir Araştırma”. Süleyman Demirel Üniversitesi İktisadi ve İdari Bilimler Fakültesi Dergisi, 21(2): 403-425.

LEONARD, G. \& SRINIVASAN, G. (2016). "Interest-Rate Swaps: Hedge or Bet? A Case of Canadian

Universities". https://www.caia.org/sites/default/files/AIAR_Q1_2016_08_LeonardSrinivasan_Hedg eorBet.pdf, (Erişim Tarihi: 15 Ocak 2021).

OCAKOĞLU, O. (2013). “Türev Ürünlerin Muhasebeleştirilmesi”. Mali Çözüm Dergisi, Kasım-Aralık 2013: 49-63.

ORACLE (2020). "IFRS 9 in Summary". https://go.oracle.com/ifrs9-compliancesummary\#IFRS9summary, (Erişim Tarihi: 15 Ocak 2021). 
ÖZULUCAN, A., ARSLAN, S. 6 KELEŞ, D. (2017). "Menkul Kiymetlerin TMS 39 ve TFRS 9 Çerçevesinde Muhasebeleştirilmesi”. Ömer Halisdemir Üniversitesi İktisadi ve İdari Bilimler Fakültesi Dergisi, 10(4): 235-249.

PROSIC, D. (2015). "Mechanism and Accounting Treatment of Interest Rate Swap". Bankarstvo, 44(1): 26-47. DOI:10.5937/bankarstvo1501026P.

PWC PRACTICAL GUIDE (2016). "General Hedge Accounting”. https://fdocuments.in/document/practical-guide-general-hedge-accounting.html, (Erişim Tarihi: 15 Ocak 2021).

SAUNDERS, K.T. (1999). "The Interest Rate Swap: Theory and Evidence”. Journal of Corporate Finance, 5 (1999): 55-78.

SELVİ, Y. (2000). “Türev Ürünlerin Muhasebeleştirilmesi”. 1. Baskı. ARC Yayınları, İstanbul.

TELCİ, A. (2021). “TFRS 9-Finansal Araçlar Standardının Portföy Yönetimi Şirketlerinin Finansal Tablolarına Etkisini Muhasebenin Önemlilik Kavramı Çerçevesinde Vaka Çalışması ile Değerlendirilmesi”. Finansal Araştırmalar ve Çalışmalar Dergisi, 13(25): 746-772.

TUNCAY, F.E. \& CENGİZ, H. (2016). "Faize Dayalı Swap Sözleşmeleri ve Muhasebeleştirilmesi”. Uluslararası İktisadi ve İdari İncelemeler Dergisi, 16: 1-22.

TÜRMOB (2020). "Swap İşlemleri İşleyişi ve Vergisel Boyutu”. https://turmob.org.tr/ekutuphane/download/0cc73f48-a0ac-4aa2-89d8-b84d7fb5c166, (Erişim Tarihi: 15 Ocak 2021).

YILMAZ, B. \& ŞAHİN, İ.E. (2009). “Türev Ürünlerinden Swap İşlemlerinin Mali Risk Yönetiminde Kullanımı”. Sosyal Ekonomik Araştırmalar Dergisi, 9(17): 393-406. 